\title{
Spanish Language
}

National Cancer Institute

\section{Source}

National Cancer Institute. Spanish Language. NCI Thesaurus. Code C120587.

An Indo-European Romance language that originated in Spain. It is the primary language of 20 countries worldwide. 